Results The results obtained in the first experiment (table 1) show a significant difference according to the type of leaf and the incorporation rate $(P<0.001)$.

The increase of foliage incorporation rate did not affect the DM intake for sweet potatoes and cocoyam; in contrast the DM intake decreased when the incorporation rate of cassava and erythrina leaves increased. These differences could be explained by differences in chemical composition (fibre content). At 35\% incorporation rate, the highest ingestibility was measured for sweet potatoes and the lowest for erythrina; Intermediate values were found for cassava and cocoyam.

On a DM basis, the presentation form influenced palatability of leaves only for cocoyam and erythrina. When fresh materials were fed to the pigs, the ingestion significantly decreased from $70 \%$ in cocoyam $(P<0.05)$ and increased from $50 \%$ for erythrina $(P>0.05)$ (Figure 1a). On a fresh basis, the best ingested material was the sweet potatoe foliages followed by the cassava and erythrina foliages (Figure 1b).

Conclusion According to our results, the palatability of tropical forages changes according to the plant species. These differences were probably related to differences in dietary fibre content and in secondary metabolites. Sweet potatoes appear to be the most suitable to be used as a fresh forage meal in pigs. The low palatability of fresh cocoyam leaves was probably related to the presence of oxalic acid. For sweet potatoes, cassava and erythrina leaves, the drying process did not improve their palatability. These results suggest that sweet potatoes, cassava and erythrina leaves could be given to pigs without any treatment to partly or completely cover their protein requirements.

\title{
Nutritional value of palm kernel cake for ruminants*
}

\author{
Natalia Guarino Souza Barbosa ${ }^{1}$, Norberto Mario Rodriguez ${ }^{1}$, Paulo Campos Christo \\ Fernandes ${ }^{2}$, Alexandre Rossetto Garcia ${ }^{2}$ and Benjamim de Souza Nahúm ${ }^{2}$ \\ ${ }^{1}$ Veterinary School-UFMG, Belo Horizonte, Brazil; ${ }^{2}$ EMBRAPA EASTER AMAZON, Belém, Brazil \\ Email:nbarbos@uol.com.br/pauloccf@cpatu.embrapa.br
}

Introduction. The use of biomass for energy production and biofuel seems to be the most promising alternative of this century, combining development and environment conservation (Hall et al., 2005). The Palm Kernel Cake (PKC), also known as Palm Kernel Meal, is estimated at having its production increased about $350 \%$ over the next five to 10 years due to Brazilian governmental programs for the palm industry. PKC is classified as a concentrate feed, mostly as an energetic source (Valadares Filho et al., 2006; NRC, 2001). This study was aimed at evaluating the intake, digestibility and in situ degradability of Dry Matter (DM), Crude Protein (CP), Neutral Detergent Fiber (NDF), Acid Detergent Fiber $(\mathrm{ADF})$, rate of passage and emptiness in buffalo receiving different levels of palm kernel cake (PKC) to determine its metabolic dynamics in the gastrointestinal tract.

Methods. Four (intake and digestibility-study 1 ) and three (in situ degradability, emptiness and rate of passagestudy 2) crossbred river steer buffaloes cannulated in the rumen with initial live weights of $380.10 \pm 27.21 \mathrm{Kg}$, kept under individual systems were fed increasing levels of Palm Kernel Cake-PKC (average of 8.23\% Ether Extract) at 0, 20, 40 and $60 \%$ plus $100,80,60$ or $40 \%$ of grass silage (Pennisetum purpureum). Animals were fed twice a day: $40 \%$ in the morning and $60 \%$ at the end of the afternoon. The Experimental design was a randomized block design for

\footnotetext{
*This project had financial support from CNPq and Palmasa Ltda.
}

study 1 and a randomized block design in split plot arrangement for study 2 . Four periods of 42 days each were used, with 14 to adjust intake and seven for each of the following studies: intake and digestibility, in situ degradability, rate of passage, and emptiness. During one year, the industry developed a standardized cake that was then used during the experiment.

Results and discussion. Best intake (\%) and digestibility (\%) level for DM, NDF, EE, CP, and digestible energy (DE) was

Table 1 Percentage of Degradation Potential (Fractions $A+B$ ) in buffalo rumen fed different levels of PKC (Palm Kernel Cake)

\begin{tabular}{|c|c|c|c|c|}
\hline \multirow[b]{2}{*}{ Level PKC (\%) } & \multicolumn{4}{|c|}{ Degradation Potencial (\%)* } \\
\hline & Silage & PKC & Silage & PKC \\
\hline & \multicolumn{2}{|c|}{$\mathrm{DM}^{* *}$} & \multicolumn{2}{|c|}{ NDF $^{* *}$} \\
\hline 0 & 62.75 & 80.18 & 60.54 & 77.94 \\
\hline 20 & 56.10 & 75.83 & 51.77 & 70.88 \\
\hline 40 & 49.64 & 69.98 & 44.83 & 60.30 \\
\hline \multirow[t]{2}{*}{60} & 49.83 & 79.76 & 51.85 & 76.68 \\
\hline & \multicolumn{2}{|c|}{$A D F * *$} & \multicolumn{2}{|c|}{$C P^{* *}$} \\
\hline 0 & 58.29 & 65.19 & 63.04 & 94.99 \\
\hline 20 & 45.19 & 57.14 & 64.43 & 70.92 \\
\hline 40 & 40.04 & 30.02 & 64.68 & 76.74 \\
\hline 60 & 50.28 & 57.50 & 57.89 & 98.38 \\
\hline
\end{tabular}

**Dry Matter (DM), Neutral Detergent Fiber (NDF), Acid Detergent Fiber (ADF) and Crude Protein (CP). 


\section{Addendum}

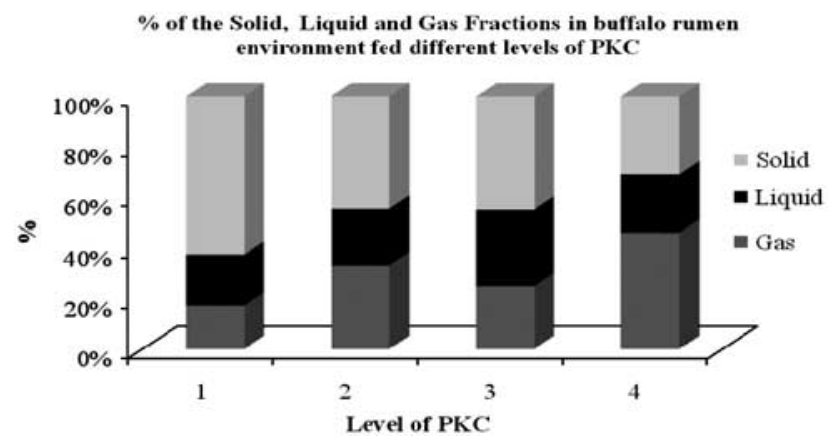

Figure 1 Percentage of solid, liquid and gas portions in buffalo rumen under different levels of palm kernel cake (PKC): $1(0 \%) 2(20 \%), 3(40 \%)$ and $4(60 \%)$.

determined to be at $60 \%$ of inclusion of PKC. The results of in situ Degradability can be seen in Table 1 and of emptiness in Figure 1.
The rate of passage varied from 1.77 to $2.06 \% / h$. The results from degradability show that PKC fiber was highly available to the animal, with better feed value than the grass silage (Table 1) and agreed with those found in the literature (Settineri et al., 1994). Emptiness, using the ball technique, shows high levels of gas fraction at $60 \%$ of PKC therefore requiring further investigation for gas quality. The current study concluded that the best level of inclusion for PKC is $60 \%$.

\section{References}

Hall DO, House JI and Scrase I 2005. Visão Geral de Energia e Biomassa. In: Uso da Biomassa para produção de energia na Indústria Brasileira. (Org.) CALLE. F. R. Campinas, Sao Paulo: Editora Unicamp, pp. 25-69.

National Research Council - NRC 2001. Nutrients requirements of dairy cattle, 7 ed. Washington, DC: National Academy Press, 381p.

Settineri D, Pace V and Catillo G 1994. Wheat straw and meadow hay acid detergent fibre and lignin degradation in the rumen of buffaloes and cattle. Effects of the dies and of the trial periods. Proceedings...IV World Buffalo Congress, ABCB/São Paulo, SP, 296-301.

Valadares Filho SC, Magalhães KA, Rocha VR Jr et al. 2006. Tabelas brasileiras de composição de alimentos para bovinos, 2 ed. Viçosa: UFV, 329p. 